\title{
CDISC SDTM Cardiovascular Findings About Test Name Terminology
}

National Cancer Institute

\section{Source}

National Cancer Institute. CDISC SDTM Cardiovascular Findings About Test Name

Terminology. NCl Thesaurus. Code C119014.

Terminology associated with the cardiovascular findings about test names codelist of the Clinical Data Interchange Standards Consortium (CDISC) Study Data Tabulation Model (SDT M). 